\title{
Analisis Perbedaan Mesh Pada Simulasi Boiler PLTGU Tanjung Priok Berbasis CFD
}

\author{
I Nyoman Agus Adi Saputra1)", I Gusti Bagus Wijaya Kusuma2), I Gusti Ngurah \\ Priambadi ${ }^{3}$
}

\author{
${ }^{1)}$ Program Studi Magister Teknik Mesin Program Pascasarjana Universitas Udayana \\ Gedung Pascasarjana, Universitas Udayana Sudirman, Bali 80113 \\ Email: gusadi5837@gmail.com, \\ ${ }^{2,3)}$ Jurusan Teknik Mesin, Fakultas Teknik, Universitas Udayana \\ Bukit Jimbaran, Bali 80362 \\ Email: wijaya.kusuma88@yahoo.com , priambadi.ngurah@yahoo.com
}

\begin{abstract}
doi: https://doi.org/10.24843/METTEK.2020.v06.i01.p06
\end{abstract}
\begin{abstract}
Abstrak
Penelitian Analisis Perbedaan Mesh berbasis Computational Fluid Dynamic (CFD) ini dilakukan Pada Boiler PLTGU Tanjung Priok. Boiler atau reboiler dalam sistem PLTGU dikategorikan sebagai alat penukar kalor karena perpindahan panasnya dilakukan tanpa kontak langsung antara media pemanas dengan media yang dipanaskan. Fluida kerja pada boiler PLTGU Tanjung Priok berupa gas methane dan air. Penelitian ini bertujuan melihat jumlah pembagian elemen terhadap hasil simulasi dengan menggunakan dua model Studi konvergensi grid yaitu dengan grid kasar, dan yang paling optimal melalui hasil simulasi CFD. Metode yang digunakan mulai dari mendesain geometri boiler sesuai kondisi di lapangan menginput initial conditions dan boundry conditions. Data hasil penelitian yang sudah di lakukan pada simulasi boiler menunjukkan bahwa baik temperatur, tekanan dan kecepatan aliran memiliki nilai yang sama besar dan tidak di pengaruhi oleh pembagian elemen yang di lakukan pada saat proses meshing dari elemen yang paling kasar dengan jumlah total sebanyak 203.363 sampai pada tahap proses meshing dengan elemen teroptimal yang berjumlah sebanyak 1.491 .428 berdasarkan hal tersebut maka proses simulasi yang dilakukan menjadi lebih efisien karena proses perhitungan data dari elemen yang lebih sedikit mendapatkan hasil yang sama dengan elemen yang lebih banyak.
\end{abstract}

Kata kunci: Boiler, Meshing, CFD, PLTGU, Tanjung Priok

\begin{abstract}
The research on Mesh Difference Analysis based on Computational Fluid Dynamic (CFD) was conducted at Tanjung Priok PLTGU Boiler. Boilers or reboilers in PLTGU systems are categorized as heat exchangers because the heat transfer is done without direct contact between the heating media and the heated media. The working fluid in the Tanjung Priok gas power plant boiler is in the form of methane gas and water. This study aims to look at the number of elements divided against the simulation results by using two grid convergence study models, namely with a coarse grid, and the most optimal through CFD simulation results. The method used starts from designing the boiler geometry according to the field conditions, inputting initial conditions and boundry conditions. Data from research that has been done on boiler simulations shows that both temperature, pressure and flow velocity have the same value and are not affected by the division of elements carried out during the meshing process of the most coarse elements with a total number of 203.363 up to the meshing process stage with the optimum elements totaling 1,491,428 based on this, the simulation process carried out becomes more efficient because the process of calculating data from fewer elements gets the same
\end{abstract}

Penulis korespondensi,

Email: gusadi5837@gmail.com 
results with more elements.

Keywords: Boiler, Meshing, CFD, PLTGU, Tanjung Priok

\section{PENDAHULUAN}

Boiler dan dalam system PLTGU dikategorikan sebagai alat penukar kalor karena perpindahan panasnya dilakukan tanpa kontak langsung antara media pemanas dengan media yang dipanaskan. Alat penukar kalor sudah banyak digunakan dalam industri-industri minyak dan gas dan hampir semuanya memiliki dimensi yang besar. Menurut Arnold (1999), reboiler telah banyak digunakan dalam industri migas terutama pada proses distilasi. Kern (1965) menyebutkan ada beberapa jenis reboiler yang digunakan dalam proses distrilasi. Klasifikasi dari reboiler tersebut berdasarkan pada sirkulasi paksa dan sirkulasi natural.

PLTGU Tanjung Priok berdiri pada lahan yang terbatas, sehingga bila akan dinaikkan kapasitas pembangkitannya maka akan menjadi masalah. Oleh sebab itu, perlu direncanakan untuk membuat mesin-mesin penukar kalor yang ada menjadi lebih ringkas. Boiler dan kondensor adalah mesin penukar kalor yang bisa dibuat ringkas. Sebelum membuat ringkas, maka perlu diketahui telebih dahulu data real dari boiler dan kondensor yang terpasang saat ini, yang meliputi: dimensi, geometri, kapasitas uap, temperatur masuk dan keluar (baik sisi gas maupun sisi air), penurunan tekanan, efisiensi dan efektivitas alat. Dimensi adalah ukuran dari suatu system yang dihitung berdasarkan kapasitas uap, temperatur dan tekanan yang sesuai dengan operasional kerjanya.

Stephane (2000) menunjukkan bahwa operating pressure sangat mempengaruhi efektivitas atau unjuk kerja thermoshipon dari reboiler. Menurut penelitian Mirmanto (2016) dinyatakan bahwa debit sangat mempengaruhi unjuk kerja dari alat penukar kalor. McNeil (2001) dalam penelitiannya menunjukkan heat flux dari sisi tube sangat berpengaruh kepada unjuk kerja dari kettle reboiler. Sementara itu Setiawan (2011) melakukan penelitian mengenai menambahan feeder pump dalam mempertahan unjuk kerja alat penukar kalor.

Berdasarkan latar belakang di atas, penulis mencoba melakukan penelitian agar Boiler di PLTGU Tanjung Priok yang memiliki ukuran besar dapat dibuat menjadi lebih ringkas namun tetap memiliki kinerja yang sama dengan kondisi saat ini. Penelitian dilakukan menggunakan simulasi Computational Fluid Dynamics (CFD), dimana pada tahap awal simulasi dilakukan dengan membuat bentuk dan geometri yang sama dengan kondisi boiler saat ini.

Tujuan dari penelitian ini adalah untuk menyelidiki perbedaan jumlah mesh dari boiler yang terdapat di Pembangkit Listrik Tenaga Gas dan Uap Tanjung Priok, dengan menggunakan dua model Studi konvergensi grid yaitu dengan grid kasar, dan yang paling optimal melalui hasil simulasi CFD baik dari Temperatur, Tekanan, dan Kecepatan Aliran pada sel mesh yang dinormalisasi untuk menentukan bagaimana kualitas mesh. mempengaruhi hasil simulasi CFD.

\section{METODE}

Penelitian ini bertujuan menganalisa unjuk kerja dari sebuah alat penukar panas antara lain adalah dengan menggunakan beberapa persamaan dalam perpindahan panas yang terjadi. Berdasarkan perpindahan panas yang terjadi maka dapat dihitung kapasitas panas yang dipertukarkan, efisiensi dan efektivitas boiler serta penurunan tekanan yang terjadi.

Tahap pertama penelitian atau Prepocessor adalah membuat geometri sesuai kondisi lapangan menginput data meliputi temperature air masuk boiler, kapasitas air feeding, kapasitas gas yang mengalir atau laju alir massa dari gas, temperature gas saat memanaskan air dan temperature gas yang keluar dari boiler, Semua data ini dimasukkan sebagai initial condition dan boundary condition.

Tahap berikutnya Processor atau proses perhitungan simulasi dengan menggunakan tools 
Run Project agar dapat mengetahui output Uap Steam yang di hasilkan. Setelah proses perhitungan selesai maka tahap selanjutnya Postprocessor dimana hasil perhitungan diinterpretasikan ke dalam gambar, grafik bahkan animasi dengan pola-pola warna tertentu.

Untuk mengetahui bahwa simulasi CFD tidak tergantung pada jumlah Mesh, maka dilakukan independensi mesh agar hasil simulasi tidak tergantung pada jumlah dan jenis mesh. Sebagai tahap awal adalah simulasi CFD dengan menggunakan Mesh paling kasar ada pada Gambar 1.a dan Mesh teroptimal pada Gambar 1.b Sebagai berikut :
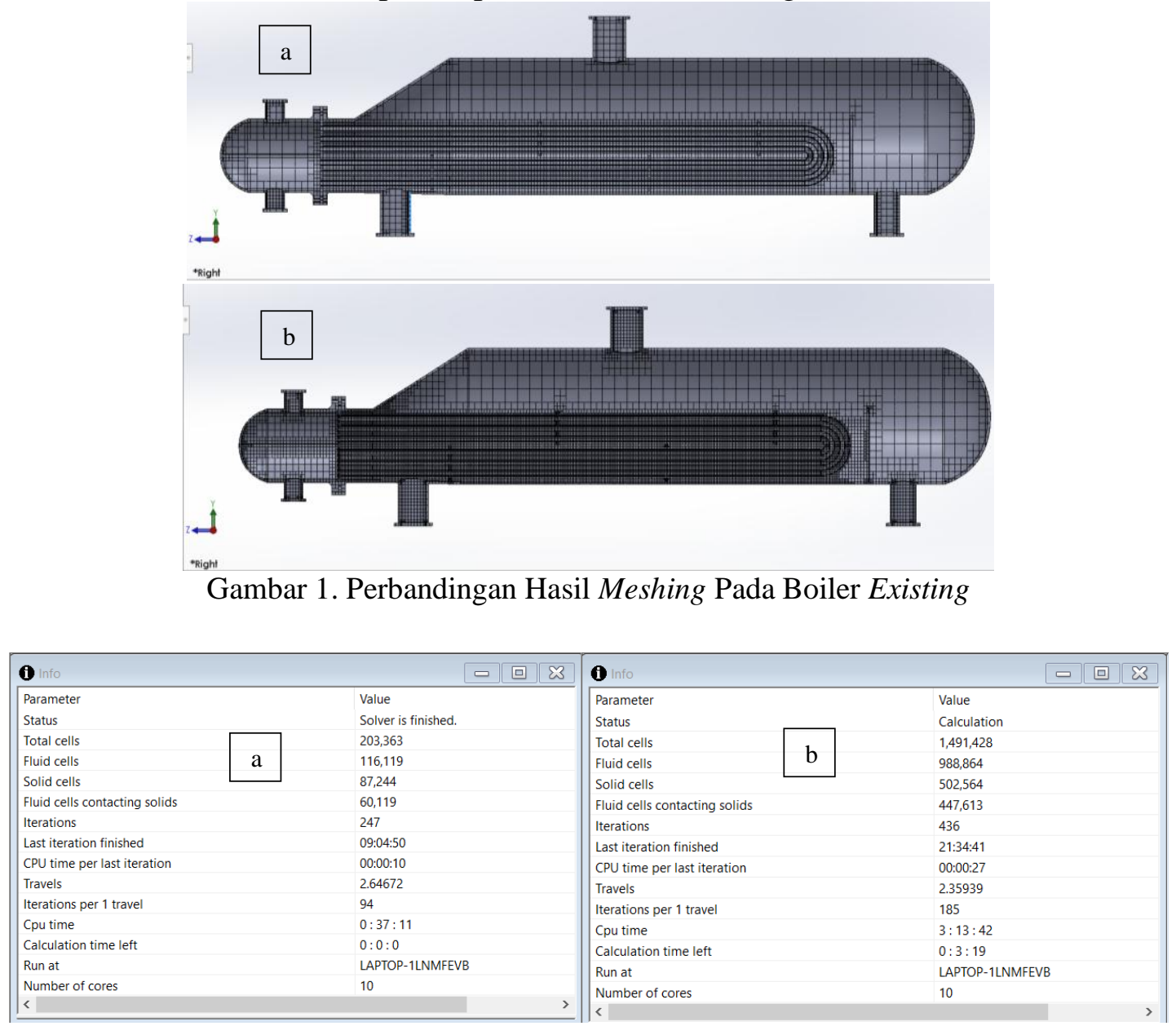

Gambar 2. Tabel Running Parameter Meshing Tipe kasar dan Optimal

Gambar diatas menunjukkan visualisasi proses meshing yang dilakukan pada boiler Pembangkit Listrik Tenaga Gas dan Uap (PLTGU) Tanjung Priok dengan tingkat meshing yang paling kasar menghasilkan total meshing sebanyak 203.363 cells pada gambar 2.a sampai dengan tingkat meshing yang paling optimal menghasilkan total meshing sebanyak 1.491 .428 cells pada gambar 2.a secara lebih detail. 


\section{HASIL DAN PEMBAHASAN}

Tabel 1. Data Penelitian

\begin{tabular}{lll}
\hline \multicolumn{2}{c}{ Fluida Gas Methane } & \multicolumn{1}{c}{ Fluida Water } \\
\hline Thi & $: 510{ }^{\circ} \mathrm{C}$ & Tci $: 53,4{ }^{\circ} \mathrm{C}$ \\
$\dot{m}_{\text {gas }}: 78,48 \mathrm{~kg} / \mathrm{s}$ & $\dot{\mathrm{m}}_{\text {uap }}: 45 \mathrm{~kg} / \mathrm{s}$ \\
$\mathrm{Phi}$ & $: 39.8 \mathrm{Bar} \approx 4032735 \mathrm{~Pa}$ & $\dot{\mathrm{m}}_{\text {air }}: 45,5 \mathrm{~kg} / \mathrm{s}$ \\
$\mathrm{Pho}$ & $: 1,25 \mathrm{Bar} \approx 126656,25$ & $\mathrm{Pci}: 2,2 \mathrm{Bar} \approx 222915 \mathrm{~Pa}$ \\
$\mathrm{~Pa}$ & & Pco $: 37,8 \mathrm{Bar} \approx 3799687,5 \mathrm{~Pa}$ \\
& Tco $: 457^{\circ} \mathrm{C}$ \\
\hline
\end{tabular}

\subsubsection{Hasil Simulasi Pada Temperatur}

Hasil simulasi yang didapatkan dari meshing tipe kasar ini terlihat pada gambar cut contours dengan proses iterasi sebanyak 247 sedangkan meshing tipe optimal hasil simulasi di dapatkan dengan proses iterasi sebanyak 436 adapun perbandingan temperatur hasil simulasi dapat di lihat pada gambar 3. Point parameter 1 merupakan inlet gas methane, point parameter 2 merupakan outlet gas methane, point parameter 3 adalah inlet air, point parameter 4 merupakan outlet uap, sedangkan point parameter 5 merupakan outlet sisa dari air yang berlebih pada boiler.

\begin{tabular}{|c|c|c|c|c|c|c|c|c|c|c|c|}
\hline \multicolumn{6}{|l|}{ 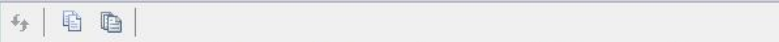 } & \multicolumn{6}{|l|}{ 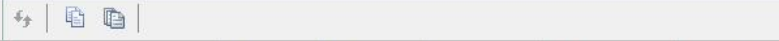 } \\
\hline Local Parameter & Minimum & Maximum & Average & Bulk Average & Surface Area & Local Parameter & Minimum & Maximum & Average & Bulk Average & Surface Area \\
\hline Temperature (Fluid) ['C] & 53.40 & 510.00 & 400.78 & 439.58 & 0.2374 & Temperature (Fluid) $\left[{ }^{\circ} \mathrm{C}\right]$ & 53.40 & 510.00 & 347.74 & 439.52 & 0.0945 \\
\hline \begin{tabular}{|l|l|l|l|l|}
$A 4$ & 4 & $P$ & M & Model \\
\end{tabular} & 3D Views & Motion & Study 1 & Surface Parame & ters 1 & \begin{tabular}{|l|l|l||l|l|}
4 & 4 & Model \\
\end{tabular} & 3D Views & Motion & Study 1 & Surface Param & ters 1 \\
\hline \multicolumn{6}{|c|}{ SOLIDWORKS Premium 2018 SP4.0 } & \multicolumn{6}{|c|}{ SOLIDWORKS Premium 2018 SP4.0 } \\
\hline
\end{tabular}

Gambar 3. Perbandingan Tabel Surface Parameter Pada Temperatur
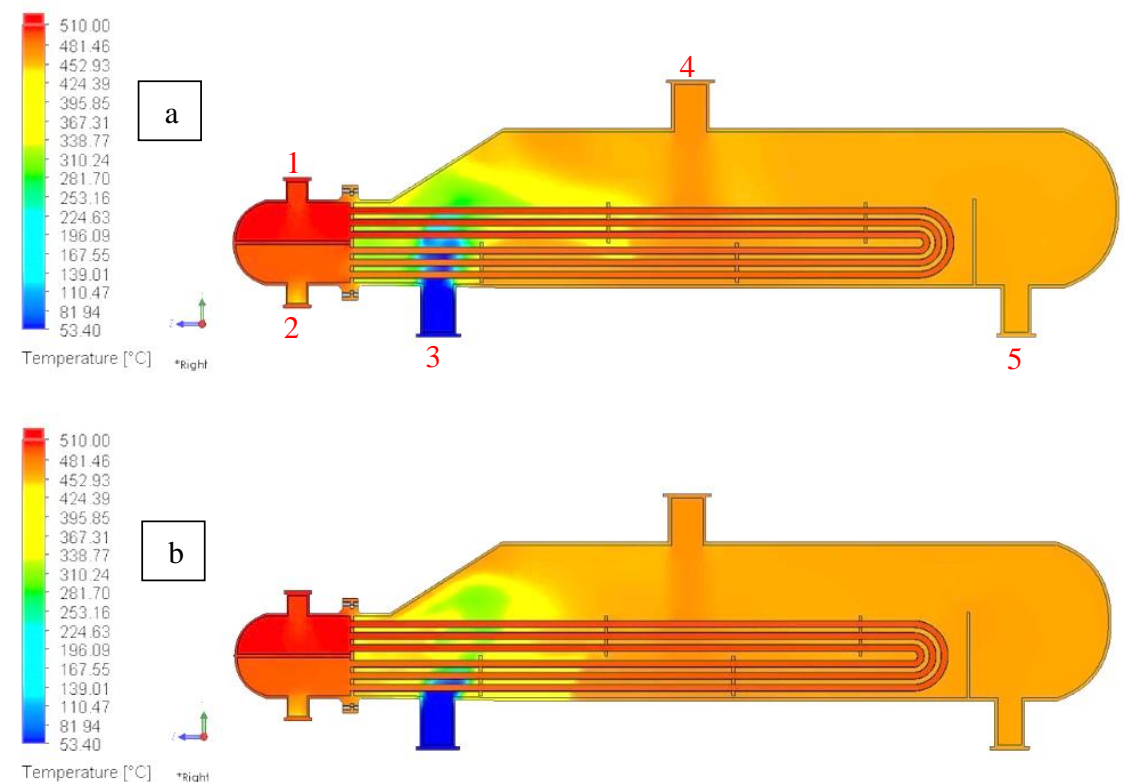

Gambar 4. Perbandingan Hasil Simulasi Temperatur Boiler Existing

Gambar 4.a merupakan hasil simulasi tipe kasar dapat diketahui bahwa nilai minimum dari temperatur di tunjukan oleh warna biru dengan nilai pada inlet air yaitu sebesar $53.4{ }^{\circ} \mathrm{C}$ sedangkan nilai maximum di tunjukan oleh warna merah dengan nilai sebesar $510{ }^{\circ} \mathrm{C}$ pada inlet gas methane dengan surface area atau elemen meshing sebesar $0.2374 \mathrm{~m}^{2}$, sedangkan gambar 4.b merupakan simulasi tipe optimal dengan hasil temperatur minimum dan 
maximum yang sama tetapi dengan surface area atau elemen meshing yang lebih kecil yaitu sebesar $0.0945 \mathrm{~m}^{2}$.

\subsubsection{Hasil Simulasi Pada Tekanan}

Hasil simulasi yang didapatkan dari meshing tipe kasar ini pada gambar 5. Tabel surface parameter dengan proses iterasi sebanyak 247 dengan elemen pada bagian fluid sebanyak 116,119 cells dan pada bagian solid sebanyak 87,244 cells. sedangkan meshing tipe optimal hasil simulasi di dapatkan dengan proses iterasi sebanyak 436 dengan elemen pada bagian fluid sebanyak 988,864 cells dan pada bagian solid sebanyak 502,564 cells. adapun perbandingan tekanan hasil simulasi dapat di lihat pada gambar 5 secara lebih rinci.

\begin{tabular}{|c|c|c|c|c|c|c|c|c|c|c|c|}
\hline \multicolumn{6}{|l|}{ 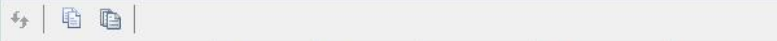 } & \multicolumn{6}{|l|}{ 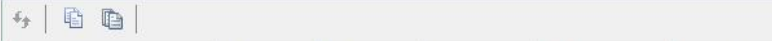 } \\
\hline Local Parameter & Minimum & Maximum & Average & Bulk Average & Surface Area & Local Parameter & Minimum & Maximum & Average & Bulk Average & Surface Area \\
\hline Pressure $[\mathrm{Pa}]$ & 4873.92 & $1.01 \mathrm{e}+07$ & 3424112.88 & 1951624.12 & 0.0945 & Pressure $[\mathrm{Pa}]$ & 4873.92 & $1.01 \mathrm{e}+07$ & 1295322.52 & $2 \quad 1981348.76$ & 0.2374 \\
\hline \begin{tabular}{|l|l|l|l|l|} 
A & A & Model \\
\end{tabular} & 3D Views & Motion & Study 1 & Surface Parame & ters 1 & \begin{tabular}{|l|l|l|l|}
$\mid$ & A & Dodel \\
\end{tabular} & 3D Views & Motion & Study $1 \quad \mathbf{S}$ & Surface Parame & ters 1 \\
\hline
\end{tabular}

Gambar 5. Perbandingan Tabel Surface Parameter Pada Tekanan
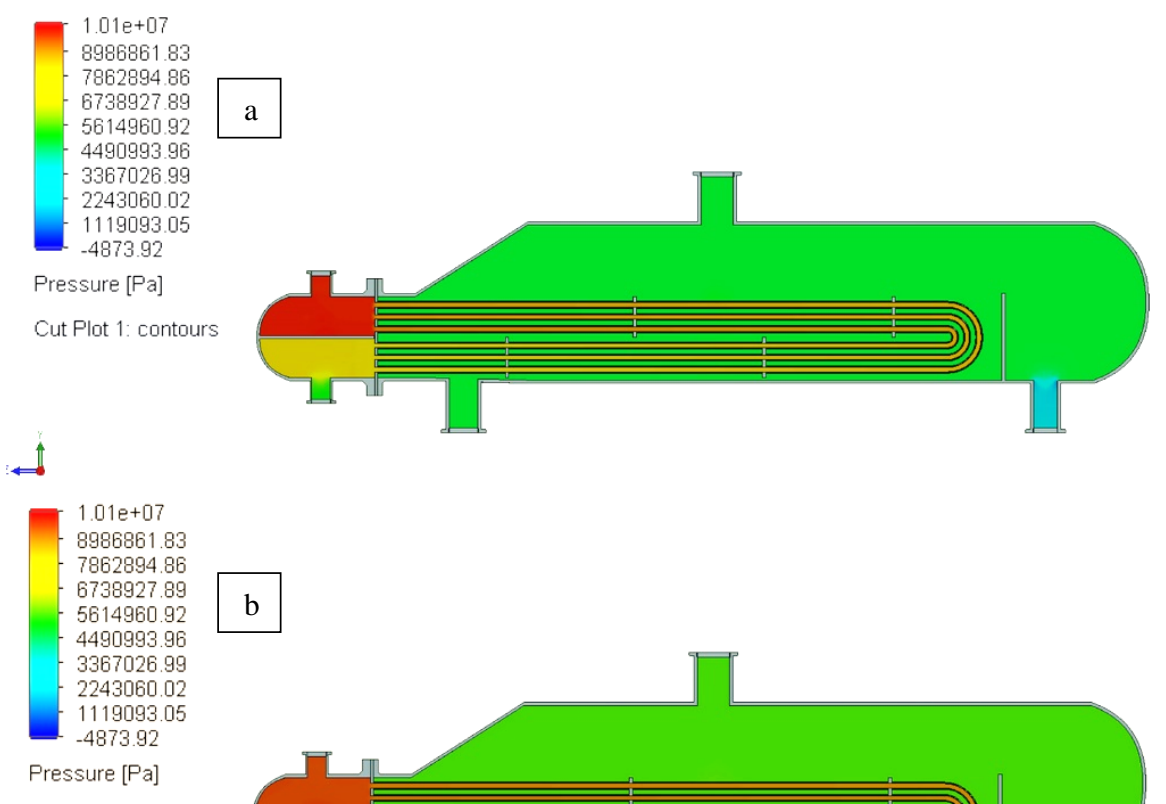

Cut Plot 1: contours

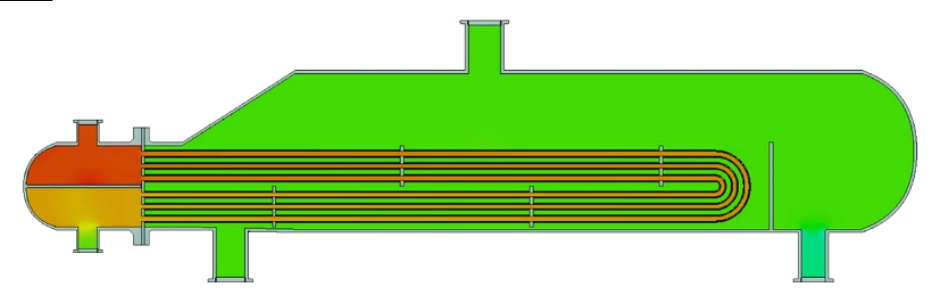

$\leftrightarrow$

Gambar 6. Perbandingan Hasil Simulasi Tekanan Boiler Existing

Gambar 6.a merupakan hasil simulasi tipe kasar dapat diketahui bahwa nilai minimum dari tekanan di tunjukan oleh warna biru pada outlet sisa uap dengan nilai sebesar 4873,92 Pa sedangkan nilai maximum di tunjukan oleh warna merah pada inlet gas methane dengan nilai sebesar 1,01E+07 dengan surface area atau elemen meshing sebesar $0.2374 \mathrm{~m}^{2}$, sedangkan gambar 6.b merupakan simulasi tipe optimal dengan hasil tekanan yang sama tetapi dengan surface area atau elemen meshing yang lebih kecil yaitu sebesar $0.0945 \mathrm{~m}^{2}$ pada gambar cut contour. 


\subsubsection{Hasil Simulasi Pada Kecepatan Aliran}

Hasil simulasi yang didapatkan dari meshing tipe kasar ini terlihat pada gambar cut contours dengan proses iterasi sebanyak 247 sedangkan meshing tipe optimal hasil simulasi di dapatkan dengan proses iterasi sebanyak 436 adapun perbandingan temperatur hasil simulasi dapat di lihat pada gambar 3 .

\begin{tabular}{|c|c|c|c|c|c|c|c|c|c|c|c|}
\hline \multicolumn{6}{|l|}{ 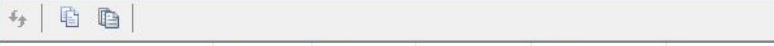 } & \multicolumn{6}{|l|}{ 4, | 笛面 } \\
\hline Local Parameter & Minimum & Maximum & Average & Bulk Average & Surface Area & Local Parameter & Minimum & Maximum & Average & Bulk Average & Surface Area \\
\hline Velocity [m/s] & 0.316 & 1.837 & 0.621 & 0.472 & 0.2374 & Velocity [m/s] & 0.316 & 1.837 & 0.690 & 0.562 & 0.0945 \\
\hline \begin{tabular}{|l|l|l|l|l|l|l|}
$\mid 4$ & 4 & Model \\
\end{tabular} & 3D Views & \multicolumn{2}{|c|}{ Motion Study 1} & \multicolumn{2}{|c|}{ Surface Parameters 1} & 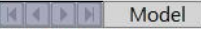 & 3D Views & Motion & Study 1 & \multirow{2}{*}{\multicolumn{2}{|c|}{ Surface Parameters 1}} \\
\hline SOLIDWORKS Premium & 2018 SP4.0 & & & & & SOLIDWORKS Premiur & 2018 SP4.0 & & & & \\
\hline
\end{tabular}

Gambar 7. Perbandingan Tabel Surface Parameter Pada Kecepatan Aliran

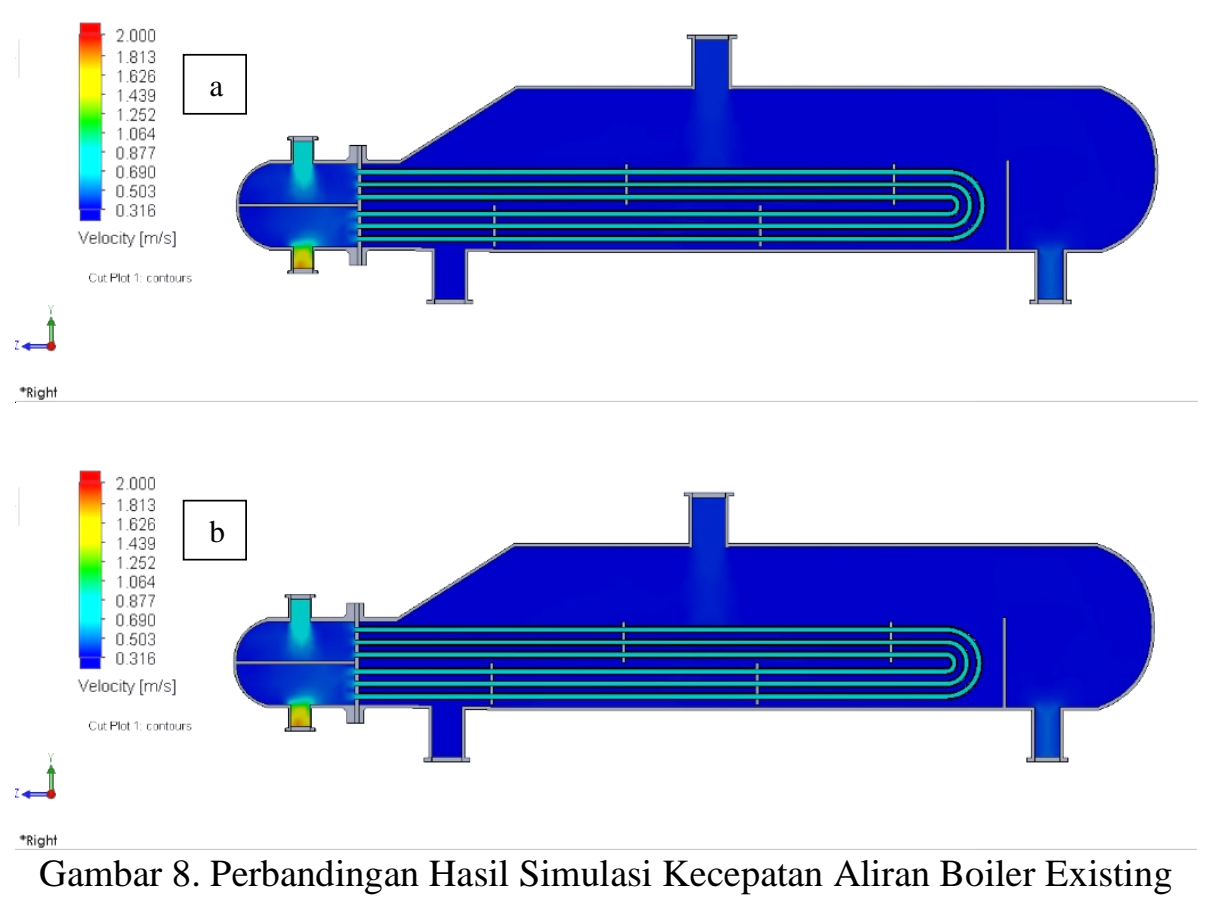

Gambar 8.a merupakan hasil simulasi tipe kasar dapat diketahui bahwa nilai minimum dari kecepatan aliran di tunjukan oleh warna biru pada bagian boiler dengan nilai sebesar $0,316 \mathrm{~m} / \mathrm{s}$, sedangkan nilai maximum di tunjukan oleh warna merah pada outlet gas methane dengan nilai sebesar $1,837 \mathrm{~m} / \mathrm{s}$ dengan surface area atau elemen meshing sebesar $0.2374 \mathrm{~m}^{2}$, sedangkan gambar 8.b merupakan simulasi tipe optimal dengan hasil kecepatan yang sama tetapi dengan surface area atau elemen meshing yang lebih kecil yaitu sebesar $0.0945 \mathrm{~m}^{2}$, dari hasil simulasi tersebut bahwa nilai kecepatan yang di hasilkan masih di bawah dari nilai batas yang di ijinkan. Berdasarkan simulasi yang telah dilakukan dari temperatur, tekanan dan kecepatan aliran maka dapat di sampaikan bahwa mesh yang di buat tidak berpengaruh terhadap hasil dari simulasi. Dengan demikian independensi mesh berhasil di lakukan.

\subsection{Pembahasan}

\subsubsection{Mencari sifat-sifat gas methane}

Diketahui dari data existing bahwa temperatur gas methane masuk sebesar $\left(\mathrm{Th}_{\mathrm{i}}\right)=510^{\circ} \mathrm{C}$ dan temperatur gas methane keluar sebesar $\left(\mathrm{Th}_{\mathrm{o}}\right)=380{ }^{\circ} \mathrm{C}$, sehingga di peroleh nilai temperatur rata-rata sebagai berikut :

$\Delta \mathrm{T} 1=\frac{T h i+T h o}{2}=\frac{(510+380)^{\circ} \mathrm{C}}{2}=445^{\circ} \mathrm{C}$ 
Sifat-sifat gas methane pada temperatur $445{ }^{\circ} \mathrm{C}=718{ }^{\circ} \mathrm{K}$ dari tabel 2.10 thermophysical properties of thirteen common gases using computer equations, dari 3 edition Handbook of Heat Transfer-New York : Mcgraw-Hill. di dapat data properties sebagai berikut :

$$
\begin{array}{lll}
\mu & =0.0000216 & \mathrm{~N} . \mathrm{s} / \mathrm{m}^{2} \\
\mathrm{k} 1 & =0.111489 & \mathrm{~W} / \mathrm{m} . \mathrm{K} \\
\mathrm{Pr} 1=0.695 & \\
\mathrm{Cp} 1=3.5886 & \mathrm{Kj} / \mathrm{kg} . \mathrm{K}
\end{array}
$$

\subsubsection{Mencari sifat-sifat air}

Diketahui dari data existing bahwa temperatur air masuk sebesar $\left(\mathrm{Tc}_{\mathrm{i}}\right)=54,3{ }^{\circ} \mathrm{C}$ dan temperatur uap keluar sebesar $\left(\mathrm{Tc}_{\mathrm{o}}\right)=457^{\circ} \mathrm{C}$, sehingga di peroleh nilai temperatur rata-rata sebagai berikut :

$$
\Delta \mathrm{T} 2=\frac{T c i+T c o}{2}=\frac{(54,3+457)^{\circ} \mathrm{C}}{2}=255,2{ }^{\circ} \mathrm{C}
$$

Sifat-sifat air pada temperatur $255,2{ }^{\circ} \mathrm{C}=528,2{ }^{\circ} \mathrm{K}$ Dari tabel A.6 Thermophysical properties of saturated water, dari 6th edition Fundamentals of Heat and Mass Transfer by Frank P. Incropera - David P. Dewwit di dapat data properties sebagai berikut :

$$
\begin{array}{rlrl}
\mu 2 & =0.000106 & \mathrm{~N} . \mathrm{s} / \mathrm{m}^{2} \\
\rho 2 & =1000 & \mathrm{Kg} / \mathrm{m}^{3} \\
\mathrm{k} 2 & =0.61034 & \mathrm{~W} / \mathrm{m} . \mathrm{K} \\
\mathrm{Pr} 2 & =1.3828 & \\
\mathrm{C} \mathrm{2} 2=4.9302 & \mathrm{Kj} / \mathrm{kg} . \mathrm{K}
\end{array}
$$

5.3.3 Menghitung laju kapasitas

$$
\begin{aligned}
& \mathrm{Ch}=\mathrm{w} 1 \cdot \mathrm{Cp} 1=\text { laju kapasitas fluida panas } \\
& =78,48 \cdot 4.9302 \quad \mathrm{Kg} / \mathrm{s} . \mathrm{Kj} / \mathrm{kg} . \mathrm{K} \\
& =281,6333 \quad \mathrm{Kw} / \mathrm{K} \\
& =45,5 \cdot 3,9132 \quad \mathrm{Kg} / \mathrm{s} . \mathrm{Kj} / \mathrm{kg} . \mathrm{K} \\
& =224,3241 \quad \mathrm{Kw} / \mathrm{K}
\end{aligned}
$$

Karena $\mathrm{Cc} \ll<\mathrm{Ch}$, Maka

$\mathrm{Cc}=\mathrm{C}$ Min, dan $\mathrm{Ch}=\mathrm{C}$ Max

$\mathrm{Cr}=\mathrm{C} \min / \mathrm{C}$ Max

$$
=224,3241 / 281,6333
$$

$$
=0.796511
$$

5.3.4 Mencari harga keefektifan Boiler

$$
\begin{array}{rlr}
\varepsilon & =\frac{c h(T h i-T h o)}{C \min (T h i-T c i)}= & \frac{C c(T c o-T c i)}{C \min (T h i-T c i)} \\
& =\frac{281,6333(510-380)}{224,3241(510-53,4)} \\
& =0,35745
\end{array}
$$

\section{SIMPULAN}

Boiler merupakan salah satu komponen yang memiliki peranan yang sangat penting yang digunakan pada PLTGU Tanjung Priok. Dalam sistem pembangkit listrik berfungsi sebagai media penukar panas. Proses simulasi yang dilakukan pada software CFD solidworks flow simulation melalui tiga tahap yaitu Prepocessor, Processor, Postprocessor. Pada proses perhitungan didapatkan hasil efektivitas boiler sebesar 0,35 . Berdasarkan pada hasil simulasi 
di temukan bahwa baik temperatur, tekanan dan kecepatan aliran adalah sama besarnya. yang memiliki grid kasar dengan proses iterasi sebanyak 247 dengan total elemen 203.363 cells sedangkan meshing tipe optimal hasil simulasi di dapatkan dengan proses iterasi sebanyak 436 dengan total elemen 1.491.428 cells. Berdasarkan hal itu dapat kita simpulkan sebagai berikut:

1. Perbedaan elemen mesh tidak akan mempengaruhi sebuah hasil apabila boundary conditions dan initial condition yang di berikan tepat.

2. Independensi Mesh tidak berpengaruh terhadap hasil sepanjang penempatan mesh di bagian yang dekat dengan dinding dilakukan secara cermat sehingga tidak dipengaruhi oleh boundary layer di dekat dinding. Sebagai akibatnya hasil simulasi tidak berpengaruh signifikan akibat adanya grid.

\section{DAFTAR PUSTAKA}

[1] Al-Kindi, Hablinur. 2015. "Analisis Computational Fluid Dynamics (CFD) Aliran Udara Panas Pada Pengering Tipe Rak Dengan Sumber Energi Gas Buang”. Sekolah Pascasarjana, Institut Pertanian Bogor.

[2] Arvirianty, A. 2019 "Menengok Nasib Mega Proyek 35 Ribu MW yang Digagas Jokowi" CNBC Indonesia 14/07/2019

[3] F. P. Incopera, D. P. Dewitt, T. L. Bergman, and A. S. Lavine, Fudamental Of Heat And Mass Transfer 6th Edition, vol. 53, no. 9. 2013.

[4] Kumar. A Et al. (2016) "3D CFD simulations of air cooled condenser-III: Thermalhydraulic characteristics and design optimization under forced convection conditions". International Journal of Heat and Mass Transfer

[5] Kupprn, T. (2000). Heat Exchanger Design Handbook. India. Marcell Dekker, Inc.

[6] Nurdianto, E. 2016. "Analisis computational fluid dynamics (CFD) dan optimalisasi untuk redesain proses akhir PENGERINGAN kopra di usaha koperasi bersama kopra putih sonia kabupaten pringsewu: Bandar Lampung".

[7] Ourliac, Mathieu. 2017. "Computational Fluid Dynamics along the Energy Value Chain: From Natural Gas processing to Industrial End-Use".

[8] Ramadhan, G.S, Luntungan H, Maluegha B. 2014. Simulasi numerik aliran fluida dalam penstock dengan menggunakan computational fluid dynamics (CFD): Manado.

[9] Rabiee, Ataollah. 2016. "Horizontal steam generator thermal hydraulic simulation in typical steady and transient conditions".

[10] Rohsenow, W, M., Hartnett, J P., \& Cho, Y. I. (1998). Handbook of Heat Transfer (Third Edition). New York : McGraw-Hill

[11] Seiwert, J. 2019. "Independent measurement of condensation and vaporisation heat transfer coefficients: An alternative to the Wilson plot method suitable for multiphase exchangers".

[12] Wei. Gaosheng. Et al. (2012) "Scheme Design and Analysis of Variable Condition of Evaporative Condenser for Steam Condensing of Steam Feeding Water Pump for 1000MW Air-cooled Unit" International Conference on Future Electrical Power and Energy Systems 